Received: $19 / 08 / 2018$

Revision: $17 / 11 / 2018$

Accepted: $22 / 11 / 2018$

OnlineFirst: 16/12/2018

\title{
Effectiveness of a Generative Learning-Based Biology Module to Improve the Analytical Thinking Skills of the Students with High and Low Reading Motivation
}

\section{Widya Prawita}

Post-Graduates Programme of Science Education, Sebelas Maret University, Indonesia, widyaprawita@student.uns.ac.id

\section{Baskoro Adi Prayitno}

Dr., Post-Graduates Programme of Science Education, Sebelas Maret University, Indonesia

\section{Sugiyarto}

Prof., Post-Graduates Programme of Science Education, Sebelas Maret University, Indonesia

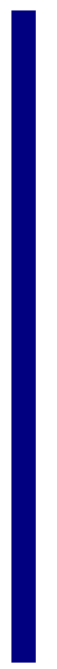

This research aimed to examine the effectiveness of a Generative Learning-based biology module to improve the analytical thinking skills of the students with high and low reading motivation. The method used was a $2 \times 2$ factorial design. The participants were 250 students of the Class XI SMA Kota Kotabumi. The researcher used an intact group technique to determine the sample. The sample was divided into two groups, namely the control group using conventional modules and the experimental group using Generative Learning-based biology modules, and each sample groups were divided into two groups of high reading motivation (HRM) and low reading motivation (LRM). The instrument used to obtain the data of analysis capability was an essay test, the indicators based on Facione's analytical thinking skills. The instrument of reading motivation used the Motivations for Reading Questionnaire (MRQ). The results of the data analysis showed the effectiveness of the Generative Learning-based biology module implementation on the students' analytical thinking skills. There was not only an influence of reading motivation through students' analytical thinking skills but also interaction between the module and students' reading motivation towards their analytical thinking skills.

Keywords: analytical thinking skill, higher order thinking skills, generative learning module, biology module, reading motivation

Citation: Prawita, W., Prayitno, B. A., \& Sugiyarto (2019). Effectiveness of a Generative LearningBased Biology Module to Improve the Analytical Thinking Skills of the Students with High and Low Reading Motivation. International Journal of Instruction, 12(1), 1459-1476. https://doi.org/10.29333/iji.2019.12193a 


\section{INTRODUCTION}

Analytical thinking skills are the ability to identify the correct intentions and conclusion relationships between statements, questions, concepts, descriptions or other forms which represent the expression of beliefs, reasons, information, and opinions needed to face the 21 st century's challenges. According to Facione (2011) the analytical thinking skills are divided into 4 indicators such as 1) interpreting information and ideas, 2) identifying the similarities and differences of the reality from the information presented, 3) developing hypotheses, and 4) describing the relationship of sentences or parts of a concept to make decision (Facione, 2011)

Analytical thinking is intelligence, analytical intelligence is one of the foundations of success (Sternberg, 1985). Analytical intelligence is capability to analyze, evaluate, judge, or compare and contrast any information (Sternberg, 2005). Analytical thinking skills is important for students to optimize their capability to solve their problems and daily problems in a long-term life (Schumacher \& Ifenthaler, 2018). This action is an important factor for developing students' analytical thinking skills which lead to 'Meaningful Learning'(Anderson, 1992; Novak \& Cañas, 2008). Meaningful learning will occur when students relate new experiences to their existing ones.

The fact that students' analytical thinking skills was still low in Indonesia. This could be seen from the Indonesia's achievements in the Trends in International Mathematics and Science Study (TIMSS). The assessment in TIMSS was measured in two domains which were the content domain and cognitive domain. The content domain was used to determine the subjects, while the cognitive domain was used to determine the thinking processes used by the students related to knowing, applying, reasoning, analyzing, evaluating, and creating. Analyzing was also included to the domain of analytical thinking skills. Based on the five times Indonesia' participation in TIMSS in 1999, 2003, 2007, 2011, and 2015, the rankings of Indonesian students were always in the low ranking countries. This low TIMSS result showed that Indonesian students were not used to solve the problems which required high-level aspects such as reasoning, applying, analyzing, evaluating, and creating (Mullis, Martin, Foy, \& Arora, 2016).

This problem in analytical thinking skills have become a concern of current researches, where the education system shifts to one which is more explicitly inclusive in learning the thinking skills in schools will be very important (Galyam \& Le Grange, 2005). This is also proven by Yee Mei Heong (2012) who states that among the 5 components of Bloom's taxonomy thinking ability, the analytical skill is the lowest (Heong et al., 2012). Similar to a research conducted by Çiğrik (2010), the analytical thinking contributes substantially to student achievement by $13.69 \%$, which includes the analytical reasoning and explanatory analysis (Çiğrik \& Ergül, 2010).

According to the observation results in the field using a test compiled based on the aspect indicators of students' analytical thinking ability showed that the students' analytical thinking skills were still relatively low. The indicator of interpreting information and ideas was $36 \%$, identifying the similarities and differences of the reality from the information presented was $36 \%$, developing hypothese was $17 \%$, and 
describing the relationship of sentences or parts of a concept to make decision was $20 \%$. The fact that the students' analytical thinking skills were still low needed to be improved (Prawita, 2018).

The analytical thinking skills could be improved through the selection of strategies, approaches, methods, models, and teaching materials which were the most suitable in terms of material characteristics and student characteristics (Areesophonpichet Sornnate, 2013; Galyam \& Le Grange, 2005; Nuangchalerm, 2009). Facts in the filed showed that learning process conducted at school had not yet trained the analytical thinking skills. Learning process which was carried out sometimes used a semi-conventional method. The lack of concept construction carried out by the students in a semi-conventional method caused the training of analytical thinking skills to not run optimally (Eldes, Prayitno, \& Sudarisman, 2014). According to Ritchie \& Volkl (2000), one effective learning model which trained the analytical thinking skills by optimizing the concept construction activities was Generative Learning (Ritchie \& Volkl, 2000).

The Generative Learning model (Wittrock, 1991) was a functional learning model of instruction which was built on knowledge of brain and cognitive processes in understanding, acquiring knowledge, attention, motivation, and transfer. The Generative Learning model required the students to learn independently, explore thier knowledge from various learning sources, focus on the problem observed, conduct an experiment to construct concepts which had been obtained, and apply them to the everyday problems (Wena Made, 2009). Students were not only passively listening to the teacher's explanation verbally, but also finding the core of the subject independently so that all activities carried out by the students were directed towards constructing the knowledge through discovery.

There was a weakness of the Generative Learning model conducted in the classroom, which was the limited time to conduct a problem focusing activity and concept construction. Students with lower academic level required a longer time than students with a higher academic level (Prayitno, Corebima, Susilo, Zubaidah, \& Ramli, 2017). The learning which focused only on the application of the learning model would be difficult to accomodate the training of analytical thinking skill of the lower academic students. Therefore, an integrated module of Generative Learning components was needed as a teaching material which was able to be used independently by the students anytime and anywhere without limited time, thus minimizing the gap in training of the analytical thinking skills between the higher academic students and lower academic students.

The Generative Learning-based biology module was the application of the Generative Learning model integrated in the modul. According to Daryanto (2013), a module was a teaching material which was able to train the students to learn independently and not be affected by other parties so that the student learning time was not limited to in the classroom only. The Generative Learning-based biology module was also integrated the Generative Learning activities such as exploration, focusing, challenges, concept applications which enabled the students to practice their analytical thinking skills independently. Therefore, a module which was integrated with a Generative Learning 
model had the potential to train the analytical thinking skills of both the lower academic students and higher academic students optimally (Daryanto, 2013).

However, the analysis of the module teaching materials in SMAN 1 Kotabumi showed that the training in every aspect of analysis thinking was still lacking. The ability to interpret information was $41 \%$, the training of identifying the similarities and differences of the reality from the information presented was $69 \%$, the training of developing hypotheses was $13 \%$, and describing the relationship of sentences or parts of a concept to make decision was $23 \%$. The fact that the components of this analytical thinking training were still low showed the need for the activity-based training module to train the analytical thinking skills which were entrusted through the Generative Learning model syntax to be applied in the module as a learning source for the students.

On the other hand, the successful application of teaching materials such as the Generative Learning-based module in the learning process was closely related to the students' reading activities (Salikin, Bin-tahir, Kusumaningputri, \& Yuliandari, 2017). Reading activities carried out by the students were largely determined by the students' reading motivation (Zusho, Pintrich, \& Coppola, 2003). Factors which influenced the different levels of students' reading motivation were partly due to the condition of the house, parental upbringing, and the lack of students' curiousity so that there was no interest in reading. Reading motivation was a positive attitude and a sense of attachment in the child to reading activities and was interested in reading books. Thus, students who had a high reading motivation had more learning readiness than the students with a low reading motivation (Wigfield, 2000). Motivation in reading is a motivation construct that has been described as a personal investment (Alexander \& Murphy, 2014) or a "relatively stable evaluative orientation toward a certain domain" (Schiefele, 2009). Highly motivation readers have feelings of involvement, stimulation, or enjoyment during reading, and tend to possess knowledge in the domain of their motivation (Renninger, 1993).

The steps of activities in the Generative Learning which were integrated in the module included the exploration stage, the students were given the opportunity to utilize the five senses as much as possible to observe the problems presented and then read the various related sources to stimulate the students' curiousity which lead to the development of a high-level reasoning power. The exploration stage encouraged the students with a low reading motivation to get the opportunity to build concepts by connecting the information obtained from daily life which had been previously owned. Second, the focusing stage, the students thought of setting ideas to solve the problems and to do examination. Third, the challenge stage, the students accepted the challenge of thinking in comparing opinions and expressed the superiority of each opinion with a scientific evidence. This exchanged of opinions could improve understanding and provide opportunities to develop ideas so as to increase the students' opportunities to develop ideas and to improve their analytical thinking skills (Purwo, 2016). Fourth, the application stage gave the students opportunities to solve the problems by applying the concepts which had been obtained. The Generative Learning stages were expected to help students both with a high reading motivation and low reading motivation in 
acquiring new knowledge about the concept in question.

Based on the description above, it was necessary to do a research aimed to (1) testing the effectiveness of the Generative Learning-based biology module on the students' analytical thinking skills, (2) testing the influence of motivation reading on the students' analytical thinking skills, (3) the influence of interaction between modules and reading motivation on analytical thinking skills.

\section{METHOD}

\section{Research Design}

This research aimed to testing the effectiveness of Generative Learning-based biology module on students' analytical thinking skills, testing the influence of motivation reading on the students' analytical thinking skills, and testing the interaction between modules and reading motivation on analytical thinking skills. Before this research, the development of product of Generative Learning-based biology module had been done by referring to research and development (R \&D) method by Borg and Gall (Sugiyono, 2011). The independent variables were the Generative Learning-based biology module and conventional module. The dependent variable was the students' analytical thinking skills. The moderator variable was the students' reading motivation. Based on the variables involved and the objectives to be achieved, the design used was a $2 \times 2$ factorial design (Creswell, 2012). The election of reading motivation as variable of moderator was based on the characteristic of module which used text. Hence, the students needed motivation of reading. The reason was supported by empiric data of regression analysis of reading motivation. The result of regression analysis showed $r=0,322$, it meant that reading motivation could predict the students' analytical thinking skill while the students was treated by different module.

The first factor was the Generative Learning-based biology module and conventional module. The second factor was the students' reading motivation which was grouped into a high and low reading motivation. The design of this research was presented in Table 1.

Table 1

Factorial Design 2x2

\begin{tabular}{|c|c|c|c|}
\hline \multicolumn{4}{|c|}{ Modules } \\
\hline & & $\begin{array}{l}\mathrm{GL} \\
\left(\mathrm{X}_{1}\right)\end{array}$ & $\begin{array}{l}\text { Convensional } \\
\left(\mathrm{X}_{2}\right)\end{array}$ \\
\hline \multirow{2}{*}{$\begin{array}{l}\text { Reading } \\
\text { Motivation }\end{array}$} & $\begin{array}{l}\text { High Reading Motivation } \\
\left(\mathrm{Y}_{1}\right)\end{array}$ & $\mathrm{X}_{1} \mathrm{Y}_{1}$ & $\mathrm{X}_{2} \mathrm{Y}_{1}$ \\
\hline & $\begin{array}{l}\text { Low Reading Motivation } \\
\left(\mathrm{Y}_{2}\right)\end{array}$ & $\mathrm{X}_{1} \mathrm{Y}_{2}$ & $\mathrm{X}_{2} \mathrm{Y}_{2}$ \\
\hline
\end{tabular}

Information:

X1 : Generative Learning-based Biology Module
X2 : Conventional Module
Y1 : High Reading Motivation


Y2 : Low Reading Motivation

X1Y1 : Student's Analytical Thinking Skill with High Reading Motivation use the Generative Learning-based Biology Module

X1Y2 : Student's Analytical Thinking Skill with Low Reading Motivation use the Generative Learning-based Biology Module

X2Y1 : Student's Analytical Thinking Skill with High Reading Motivation use the Conventional Modules

X2Y2 : Student's Analytical Thinking Skill with Low Reading Motivation use the Conventional Modules

The analysis of research aim used ancova. The utilization of ancova to analyze the data could find out the influence between independent variable through dependent variable. Furthermore, to find out the influence of dependent variable through moderator variable and then to find out the interaction between independent variable and moderator variable through dependent variable in one of analysis activity.

\section{Participants}

This research was conducted at SMA Negeri 1 Kotabumi, Indonesia, academic year of 2017/2018, on the 250 students of XI IPA which divided into seven classes. Sampling was conducted by an intact group technique, determining two groups of sample classes according to the research needs to be given treatment in the form of a module. The selected sample was XI IPA 6 class as the control class (by using conventional module) and XI IPA 7 as the experimental class (by using Generative Learning-based biology module).

Students in each sample class were grouped into two groups: high reading motivation $(\mathrm{HRM})$ and low reading motivation (LRM). Students in each sample class were grouped based on the value of reading motivation questionnaire. According to the result of reading motivation questionnaire showed that there were 23 HRM students and 13 LRM students in control class, then 24 HRM students and 12 LRM students in experiment class. The researcher chose to use 12 students as the sample of HRM and LRM to equalize sample in each class. Thus, the total sample was 48 students. The research sample was ilustrated in table 2 .

Table 2

Sample Distribution

\begin{tabular}{llllll}
\hline Class & $\sum_{\text {jtudents }}$ & $\sum_{\text {HRM }}$ & $\sum_{\text {LRM }}$ & Treatment & $\begin{array}{l}\text { Reading Motivation } \\
\text { Score } \\
\text { (Wahyuningsih \& } \\
\text { Mustadi, 2018) }\end{array}$ \\
\hline $\begin{array}{l}\text { Control } \\
\text { class }\end{array}$ & 36 & 12 & 12 & Conventional Module & $\begin{array}{l}\text { HRM : 63,01-78,11 } \\
\text { LRM : 50,09-60,00 }\end{array}$ \\
\hline $\begin{array}{l}\text { Experiment } \\
\text { class }\end{array}$ & 36 & 12 & 12 & $\begin{array}{l}\text { Generative Learning- } \\
\text { based Biology Module }\end{array}$ & $\begin{array}{l}\text { HRM : 64, 15-79,24 } \\
\text { LRM : 53,96-60,00 }\end{array}$ \\
\hline
\end{tabular}




\section{Instrumentation and Data Collection Technique}

The instruments for data collection in this research included essay analysis analytical skills test and reading motivation questionnaires. The test in this research was a written test which was compiled using the analytical thinking skills rubric according to facione (2011), consisting of 4 indicators such as: (1) interpreting information and ideas, (2) identifying the similarities and differences of the reality from the information presented, (3) developing hypotheses, and (4) describing the relationship of sentences or parts of a concept to make decision. Prior to use for data retrieval of students' analytical thinking skills, the test instrument had passed the validation by an expert validator, a lecturer of education and science (Facione, 2011).

The next instrument was a student reading motivation questionnaire. This sheet was to measure the level of students' reading motivation in learning. It was consisted of 53 statements taken from the Motivations for Reading Questionnaire (MRQ) developed by Wigfield \& Guthrie (Guthrie, 2010).

\section{Data Analysis Techniques}

Data analysis techniques used a descriptive statistical analysis and inferential statistical analysis. The descriptive statistical analysis was used to describe or explain the data which had been collected about the profile of students' analytical thinking skills and reading motivation in the application of generative learning based biology modul and conventional modul. While the inferential statistical analysis was used to analyze the acquisition of data from the results of the analytical thinking skills test. The data of this research were analyzed using the Ancova test of 0.05 significance level with the pretest score as the covariate. Prior to the Ancova test, a prerequisite test was conducted, the normality test using Lilifors test and homogeneity test using the Levene's test. All the tests used the SPSS program version 25.

\section{FINDINGS}

\section{The Development Results of the Generative Learning-based Biology Module}

Generative Learning-based Biology Module was a module designed based on a Generative Learning syntax which required the students to be actively involved during the learning process in connecting newideas with the cognitive structure (knowledge) which the students had. It consisted of components which contained learning objectives, learning materials, learning methods, tools or media, as well as learning and evaluation resources.

The syntax of Generative Learning model consisted of four which were exploration, focusing, challenges, and concept applications (Wena Made, 2009). In the exploration stage, the students were given the opportunity to utilize the five senses as much as possible to stimulate the students' curiousity which lead to the development of a highlevel reasoning power. The students got the opportunity to build concepts by connecting the information obtained from daily life which had been previously owned. The focusing 
stage, the students thought of setting ideas in solving the problems and doing the experiment. The challenge stage, the students accepted the challenge of thinking in comparing opinions and expressed the superiority of each opinion with a scientific evidence. This exchanged of opinions could improve understanding and provide opportunities to develop ideas so as to increase the students' opportunities to develop ideas and to improve their analytical thinking skills (Purwo, 2016).

The application concept stage, the students were given the opportunities solve the problems by applying the concepts which had been obtained. The syntax of the model could encourage the students to empower the higher thinking processes so that the Generative Learning model-integrated biology module had the potential to enable training the analytical thinking skills. Activities which were expected from the students were visualized in Table 3.

Table 3

The Expected of the Generative Learning syntax to activities in the Module

\begin{tabular}{lll}
\hline GL Syntax & Module Activities & $\begin{array}{l}\text { Activities which were } \\
\text { expected from the students }\end{array}$ \\
\hline Exploration & $\begin{array}{l}\text { Students would be given a stimulus } \\
\text { in the form of several activities } \\
\text { observing phenomena in the form of } \\
\text { images and searching a problem } \\
\text { which could show the data and fact } \\
\text { related to the concepts learned. }\end{array}$ & $\begin{array}{l}\text { Observing the images and } \\
\text { then making questions related } \\
\text { to the images seen. }\end{array}$ \\
\hline Focusing & $\begin{array}{l}\text { Students would be given direction, } \\
\text { guidance, and learning resources to } \\
\text { test the hypotheses through } \\
\text { laboratory activities or in other } \\
\text { learning model (group work). }\end{array}$ & $\begin{array}{l}\text { Conducting testing activities } \\
\text { from the hypotheses through } \\
\text { laboratory activities or in } \\
\text { other learning model (group } \\
\text { work). }\end{array}$ \\
\hline Challenges & $\begin{array}{l}\text { Students would be given worksheets } \\
\text { so that they were able to conduct } \\
\text { their practicum activities }\end{array}$ & $\begin{array}{l}\text { Conducting practicum } \\
\text { activities in accordance with } \\
\text { the work instruction. }\end{array}$ \\
& $\begin{array}{l}\text { Students would be given essay } \\
\text { questions related to the everyday life } \\
\text { phenomena. }\end{array}$ & $\begin{array}{l}\text { Problem solving by using new } \\
\text { concepts or real concepts of } \\
\text { the new knowledge }\end{array}$ \\
\hline Concept Application & & \\
& &
\end{tabular}


The following was the module developed by the Generative Learning syntax:

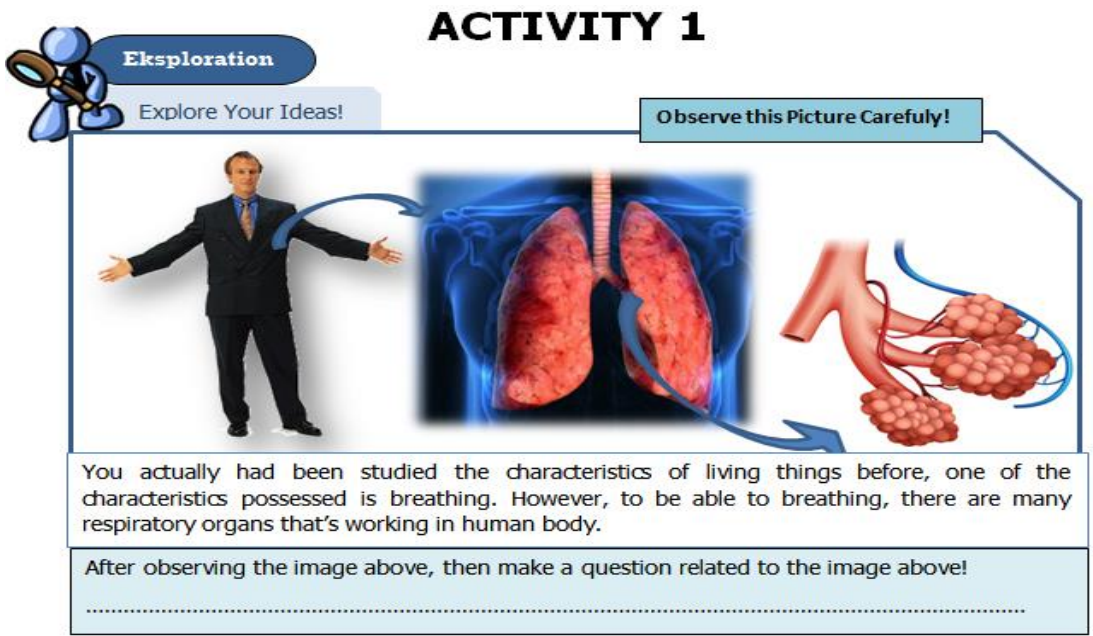

Figure 1

The Exploration Stage in the generative learning model in the module

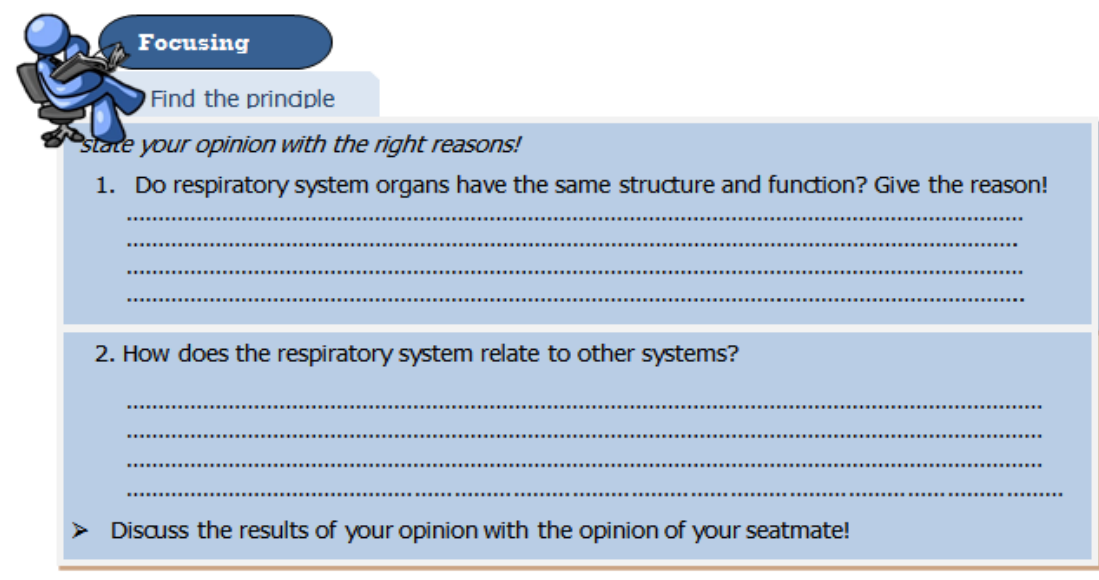

Figure 2

The Focusing Stage in the Generative Learning Model in the Module 


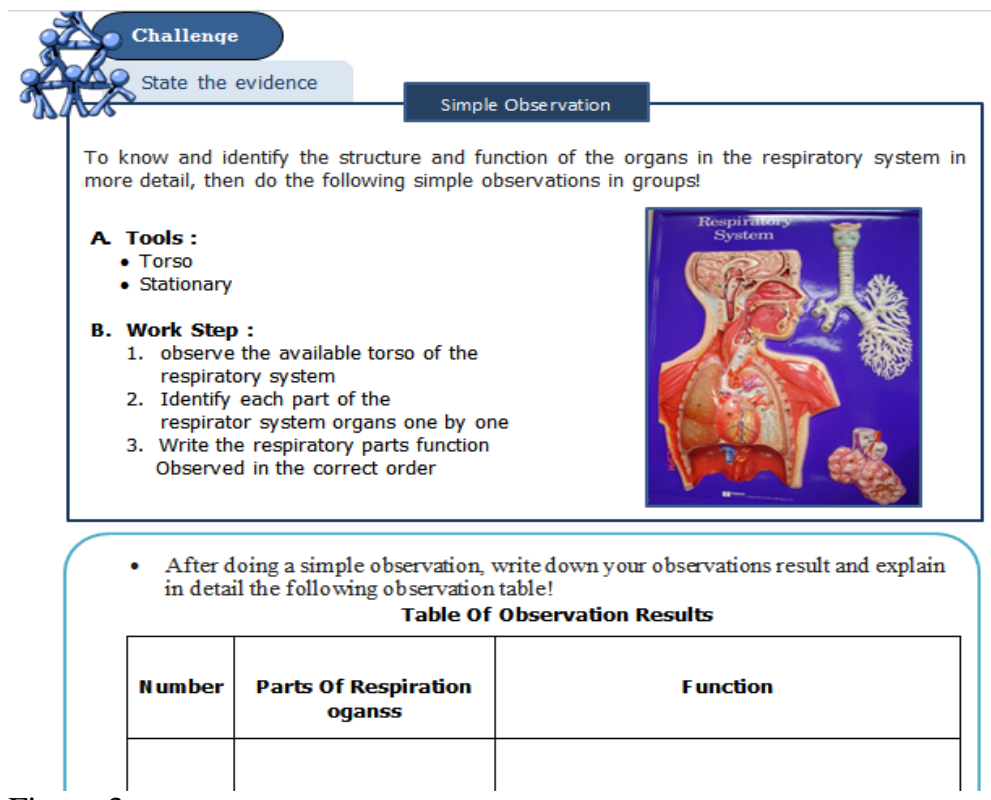

Figure 3

The Challenges stage in the Generative Learning Model in the Module

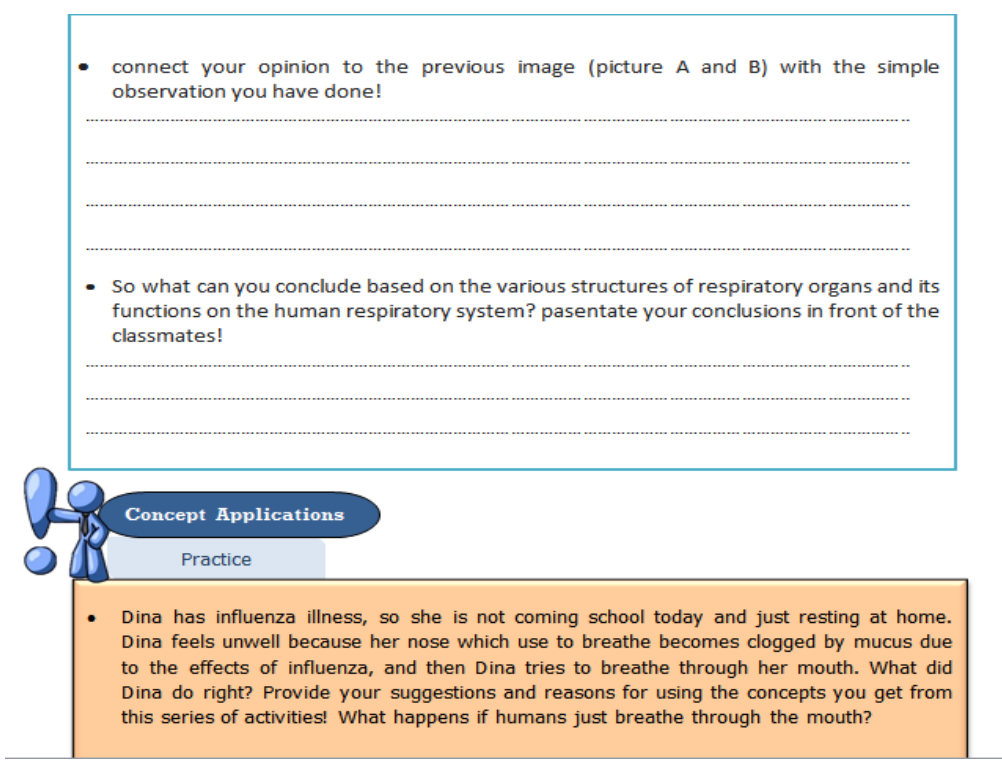

Figure 4

The Concept Applications stage in the Generative Learning Model in the Module 
The Application Results of the Generative Learning-based Biology Module on the Students' Analytical Thinking Skills and Reading Motivation

Based on the results of the analysis using a SPSS 25 program, it showed that the normality test results of the students' analytical thinking skills had a value of 0.076 . So, the sample from the population of class XI IPA was normally distributed.

The homogeneity test results also showed the results of $p .>0.05$, which was 0.598 . It meant that the data of the students' analytical thinking skills had the same or homogeneous variance. Based on the results, the data of this research fulfilled the requirements for the ANCOVA parametric statistical test.

The ancova test results of the analytical thinking skills in the learning module, reading motivation, and the interaction of learning modules with the reading motivation were presented in Table 4.

Table 4

The Ancova Test results of the students' analytical thinking skills

\begin{tabular}{llllll}
\hline Source & $\begin{array}{l}\text { Type III Sum of } \\
\text { Squares }\end{array}$ & df & Mean Square & F & $p$ \\
\hline Corrected Model & $4034.107^{\mathrm{a}}$ & 4 & 1008.527 & 53.863 & .000 \\
Intercept & 4344.372 & 1 & 4344.372 & 232.022 & .000 \\
pretest & 177.041 & 1 & 177.041 & 9.455 & .004 \\
modules & 1021.196 & 1 & 1021.196 & 54.539 & .000 \\
reading_motivation & 1602.779 & 1 & 1602.779 & 85.600 & .000 \\
module* & 96.310 & 1 & 96.310 & 5.144 & .028 \\
reading_motivation & 805.131 & 43 & 18.724 & & \\
Error & 249477.062 & 48 & & & \\
Total & 4839.238 & 47 & & & \\
Corrected Total & 48 & & & \\
\hline
\end{tabular}

a. $\mathrm{R}$ Squared $=.834$ (Adjusted R Squared $=.818$ )

In the data source model, the sig. number obtained was sig. $=0.000(<\alpha=0.05)$, that is mean there was difference in analytical thinking skills between the Generative Learning and the conventional modules. So, it was concluded that there was a significant influence of Generative Learning-based biology module on the students' analytical thinking skills. The analysis results of the difference of the module effects on the analytical thinking skills were visualized in Table 5. 
Table 5

The Average Corrected Score of the Analytical Thinking Skills by the module data source

\begin{tabular}{llllc}
\hline Modules & $\begin{array}{l}\text { Pretest } \\
\text { average }\end{array}$ & $\begin{array}{l}\text { Postest } \\
\text { average }\end{array}$ & Difference & Average Corrected \\
\hline Generative Learning & 44.968 & 76.739 & 31.770 & 76.188 \\
Convensional & 40.979 & 66.041 & 25.062 & 66.592 \\
\hline
\end{tabular}

Table 3 presented the data of students using the Generative Learning-based biology module which was significantly different from the conventional module. The Generative Learning-based biology module had an average analytical thinking skills corrected value of 76.188. it was higher than the conventional module which only had an average corrected value of 66.592. this showed that student group using the Generative Learning-based biology module had higher analytical thinking skills compared to the group using the conventional module. The analysis results of the difference of the reading motivation effect on the analytical thinking skills were visualized in Table 6.

Table 6

The Average Corrected Score of Analytical Thinking Skill by Reading Motivation Data Score

\begin{tabular}{lllll}
\hline $\begin{array}{l}\text { Motivation } \\
\text { Reading }\end{array}$ & Pretest Average & $\begin{array}{l}\text { Postest } \\
\text { Average }\end{array}$ & Different & $\begin{array}{l}\text { Average } \\
\text { Corrected }\end{array}$ \\
\hline High & 45.937 & 78.489 & 32.552 & 77.671 \\
Low & 40.010 & 64.291 & 24.281 & 65.109 \\
\hline
\end{tabular}

Table 6 presented the data of high reading motivation (HRM) which significantly different from low reading motivation (LRM). Students with high reading motivation (HRM) had average corrected value of analytical thinking skill of 77.671. it was higher than low reading motivation (LRM) which only had average corrected of 65.109. It showed that group of student with high reading motivation (HRM) had analytical thinking skill which was higher than students with low reading motivation (LRM).

Talking about reading motivation of students, the result of ancova test in table 4 previously showed significant value of interaction data between module and reading motivation of $0.028(<0.05)$, thus revealed that there was difference in learning module interaction with learning motivation toward analytical thinking skill. Therefore, it was concluded that there was interaction of learning module with reading motivation toward analytical thinking skill. Each position of interaction of learning module with reading motivation was tested using LSD test with significance level of $<0.05$ presented in table 7. 
Table 7

LSD Test Result of Interaction of Learning Module of Reading Motivation toward Analytical Thinking Skill

\begin{tabular}{llllll}
\hline Interaction & Postest & Pretest & Different & $\begin{array}{l}\text { Average } \\
\text { Corrected }\end{array}$ & Notation \\
\hline Convensional*LRM & 50.104 & 37.041 & 23.062 & 60.104 & $\mathrm{a}$ \\
GL*LRM & 58.479 & 42.979 & 25.500 & 68.479 & $\mathrm{~b}$ \\
Convensional*HRM & 72.5 & 45.568 & 26.931 & 71.979 & $\mathrm{~b}$ \\
GL*HRM & 85 & 46.958 & 38.041 & 85 & $\mathrm{c}$ \\
\hline
\end{tabular}

Table 7 showed students with high reading motivation (HRM) applied in Generative Learning based biology module had significantly different from group of student with low reading motivation (LRM) applied in Generative Learning based biology module, and conventional module applied to HRM and LRM student. It can be seen from average corrected of interaction between GL and HRM students had the highest score. It was 85. The result indicated that GL module which was applied for HRM students was more effective than another interactions. The aplication of conventional module for HRM students had the same notation with the notation of GL module for LRM students. The result showed that there was no significant different in students' analytical thinking skill between both of the interactions. However, average corrected of conventional module which was applied for students showed HRM students had higher analytical thinking skill than the GL module which was applied for LRM students. Using the conventional module for LRM students showed the result of analytical thinking skill was the lowest than all the interactions.

\section{DISCUSSION}

Result of ancova test proved that there was significant effect of module application toward improvement of students' analytical thinking skill. That significant effect could be said that activities in module could accommodate each indicator of analytical thinking skill in decent. Hence Generative Learning based biology module could improve students' analytical thinking skill.

The comparison of average corrected of learning module data source showed indicated that Generative Learning based biology module had potential in improving analytical thinking skill more significant than using conventional module. In other words, students who used Generative Learning based biology module had higher analytical thinking skill than students who used conventional module. It occurred because Generative Learning based biology module had many activities in learning stages. Those activities made serious effort to develop analytical thinking skill. Model based constructivise theory would make the students felt trigger to do the activity (Osborne \& Wittrock, 1985). Whereas there is only a little activity in the conventional module, so they lack involvement in constructing knowledge during the learning process. The Conventional strategy has little contribution to facilitating students' knowledge construction (Prayitno, Corebima, Susilo, Zubaidah, \& Ramli, 2017) 
Many students activity could empower students' thinking process. It could occur in active process when students built meaning system and understanding about the fact through their experiences and interactions in learning sources or with their friends (Robbins, 2011). So it triggered students to search many information through reading. According to Piaget, each individual had innate nature of curiosity and always tried to understand the environment (Anderson, 1992).

Students with high reading motivation (HRM) using conventional module or Generative Learning based biology module had potential to improve analytical thinking skill. Yet, students with low reading motivation (LRM) using Generative Learning based biology module had improvement in analytical thinking skillwhich was almost the same as students with high reading motivation (HRM) that used conventional module. It happened because students who used Generative Learning based biology module were required to be able to have idea, observe, show data and fact related to learning concept of students' learning motivation.

With reading motivation, students had more information so it was easy for students to do syntax of Generative Learning which was integrated in module especially in syntax of exploration, focusing and challenge. In addition, module characteristic was User Friendly. It eases students to learn using simple language and easy to understand (Daryanto, 2013). Module was also presented communicatively, it was like there was interaction between teacher and students. So students with high reading motivation or low reading motivation (LRM) would be accommodated by using module especially Generative Learning based biology module and it impacted in the improvement of analytical thinking skill.

Analytical thinking skill was important ability in $21^{\text {st }}$ century that could be used by students to solve the problem, either in learning problem or problems in daily life (Facione, 2015). Analytical thinking skill encouraged students to process the information so it could obtain a conclusion not only to remember the information directly (Nuangchalerm, 2009). However, students with high reading motivation (HRM) has higher analytical thinking skill that students with low reading motivation (LRM). Therefor, students with low reading motivation (LRM) should improve analytical thinking ability through reading learning reading material such as Generative Learning based biology module that had activity or activity that accommodated reading interest in improving analyical thinking skill.

Students' analytial thinking skill with high reading motivation (HRM) used conventional module with students' analytical thinking skill with low reading motivation (LRM) used Generative Learning based biology module had no difference significantly. It proved that Generative Learning based biology module still could accommodate students' low learning motivation (LRM) in improving analitically thinking skill. It meant that if students' high reading motivation (HRM) was applied in conventional module, it would have good result of analytical thinking ability because students with high reading motivation (HRM) had high thinking level ability. Students who had high reading motivation would have high thinking ability at school, in contrast, students who had low reading motivation would had low thinking ability (Guthrie, Wigfield, Jamie, \& Cox, 
2009). Students' understanding of concepts will increase as they become more experienced with reading (Probosari, Widyastuti, Sajidan, Suranoto, \& Prayitno, 2018).

However, it was different from conventional module, Generative Learning based biology module still could accommodate students with low reading motivation (LRM) to be able to improve analytical thinking skill. Biology module based Generative learning was arranged by the integration between syntax of Generative Learning model with indicators of analytical thinking skill. Many activities in Generative Learning based biology module triggered students' activeness and curiosity so students with low reading motivation (LRM) still could improve their analytical thinking skill.

\section{CONCLUSION}

The conclusion of this research is Generative Learning based biology module is developed based generative learning activities. Generative Learning based biology module is more effective in improving students' analytical thinking skill than conventional module. Interaction of Generative Learning based biology module in students with high reading motivation (HRM) has highest analytical thinking skill. On the other hand, Interaction of Generative Learning based biology module in students with low reading motivation (LRM) has the same analytical thinking skill with interaction of conventional module in students with high reading motivation (HRM). The fruitfulness of applying the module must be accompanied by encouraging students' reading motivation.

\section{REFERENCES}

Alexander, P. A., \& Murphy, P. K. (2014). Profiling the Differences in Students â $€^{\mathrm{TM}}$ Knowledge, Interest, and Strategic Processing, (September 1998). https://doi.org/10.1037/0022-0663.90.3.435

Anderson, R. (1992). Some Interrelationships between Constructivist Motiels of Learning and Current Neurobiological Theory, with Implications for Science Education, 29(10), 1037-1058.

Areesophonpichet Sornnate. (2013). A Development of Analytical Thinking Skills of Graduate Students by using Concept Mapping. The Asian Conference on Education 2013, 1-16.

Çiğrik, E., \& Ergül, R. (2010). The investion effect of using WebQuest on logical thinking ability in science education. Procedia - Social and Behavioral Sciences, 2(2), 4918-4922. https://doi.org/10.1016/j.sbspro.2010.03.795

Creswell, J. W. (2012). Educational Research (4th ed.). Boston: Pearson.

Daryanto. (2013). Menyusun Modul Bahan Ajar Untuk Persiapan Guru Dalam. Mengajar. Yogyakarta: Gava Media.

Eldes, I., Prayitno, B. A., \& Sudarisman, S. (2014). Pembelajaran Biologi Dengan Generative Learning Model (GLM) Disertai Media Dickey dan Polkey Ditinjau Dari 
Kemampuan Berpikir Kritis dan Analitis. Inkuiri, 3(2).

Facione, P. A. (2011). Critical Thinking: What It Is and Why It Counts. Insight Assessment, (ISBN 13: 978-1-891557-07-1.), 1-28. https://doi.org/ISBN 13: 978-1891557-07-1.

Facione, P. A. (2015). Critical Thinking: What It Is and Why It Counts, 1-30.

Galyam, N., \& Le Grange, L. (2005). Improving Thinking Skills in Science of Learners with (dis)abilities. South African Journal of Education, 25(4), 239-246. Retrieved from http://reference.sabinet.co.za/webx/access/electronic_journals/educat/educat_v25_n4_a4 .pdf

Guthrie, J. T. (2010). Journal of Educational Psychology, 89 , 420-432.

Guthrie, J. T., Wigfield, A., Jamie, L., \& Cox, K. E. (2009). Scientific Studies of Reading Motivational and Cognitive Predictors of Text Comprehension and Reading Amount, (October 2014), 37-41. https://doi.org/10.1207/s1532799xssr0303

Heong, Y. M., Yunos, J. M., Othman, W., Hassan, R., Kiong, T. T., \& Mohamad, M. M. (2012). The Needs Analysis of Learning Higher Order Thinking Skills for Generating Ideas. Procedia - Social and Behavioral Sciences, 59, 197-203. https://doi.org/10.1016/j.sbspro.2012.09.265

Mullis, I. V. S., Martin, M. O., Foy, P., \& Arora, A. (2016). The TIMSS 2011 International Results in Mathematics. The TIMSS 2015 International Results in Mathematics, 17-183. https://doi.org/10.1002/yd.20038

Novak, J. D., \& Cañas, A. J. (2008). The Theory Underlying Concept Maps and How to Construct and Use Them 1. Florida Institute for Human and Machine Cognition, 1-36.

Nuangchalerm, P. (2009). Cognitive Development, Analytical Thinking and Learning Satisfaction of Second Grade Students Learned through Inquiry-based Learning. Asian Social Science, 5(10), 82-87.

Osborne, R., \& Wittrock, M. (1985). Studies in Science Education The Generative Learning Model and its Implications for Science Education. https://doi.org/10.1080/03057268508559923

Prawita, W. (2018). Pengembangan Modul Sistem Pernapasan Berbasis Generative Learning untuk Meningkatkan Kemampuan Berpikir Analisis Peserta Didik Kelas XI SMA. Universitas Sebelas Maret.

Prayitno, B. A., Corebima, D., Susilo, H., Zubaidah, S., \& Ramli, M. (2017). Closing The Science Process Skills Gap Between Students With High dan Low Level Academic Achievement. Journal of Baltic Science Education, 162(2), 266-277.

Probosari, R. M., Widyastuti, F., Sajidan, S., Suranoto, S., \& Prayitno, B. A. (2018). 
Reading for tracing evidence: developing scientific knowledge through science text Reading for tracing evidence: developing scientific knowledge through science text. Journal of Physics: Conf. Series, 1022(The 1st International Conference on Science, Mathematics, Environment and Education). https://doi.org/10.1088/17426596/1022/1/012019

Purwo, W. (2016). Makalah Pendamping Peran Pendidik dan Ilmuwan dalam Menghadapi MEA ISSN : 2527-6670 Pengembangan Modul Fisika Berbasis Generative Learning Untuk Meningkatkan Kemampuan Berpikir Kritis Siswa, 66-71.

Renninger, K. A. N. N. (1993). Individual Interest and Its Implications for Understanding Intrinsic Motivation.

Ritchie, D., \& Volkl, C. (2000). Effectiveness of Two Generative Learning Strategies in the Science Classroom, 100(February).

Robbins, J. K. (2011). Problem Solving, Reasoning, and Analytical Thinking in a Classroom Environment, 12(1).

Salikin, H., Bin-tahir, S. Z., Kusumaningputri, R., \& Yuliandari, D. P. (2017). The Indonesian EFL Learners , Motivation in Reading, 10(5), 81-90. https://doi.org/10.5539/elt.v10n5p81

Schiefele, U. (2009). Scientific Studies of Reading Interest and Learning From Text, (November 2014), 37-41. https://doi.org/10.1207/s1532799xssr0303

Schumacher, C., \& Ifenthaler, D. (2018). Features students really expect from learning analytics. Computers in Human Behavior, 78(Celda), 397-407. https://doi.org/10.1016/j.chb.2017.06.030

Sternberg, R. J. (1985). Beyond IQ: A Triarchic Theory of Human Intelligence. Cambridge: Cambridge University Press.

Sternberg, R. J. (2005). The theory of successful intelligence. Interamerican Journal of Psychology, 39(2), 189-202. https://doi.org/10.1037/1061-4087.55.3.139

Sugiyono. (2011). Metode Penelitian Kuantitatif Kualitatif dan R\&D. Bandung: CV Alfabeta.

Wahyuningsih, S., \& Mustadi, A. (2018). Tingkat Motivasi Menbaca Siswa Dilihat Dari Perilaku Sosial Yang Menunjukkan Sikap Minat Membaca, (January), 0-9.

Wena Made. (2009). Strategi Pembelajaran Inovastif Kontemporer. Jakarta: Bumi Aksara.

Wigfield, A. (2000). Expectancy - Value Theory of Achievement Motivation, 81, 6881. https://doi.org/10.1006/ceps.1999.1015

Wittrock, M. C. (1991). Generative Teaching of Comprehension, 92(2). 
Zusho, A., Pintrich, P. R., \& Coppola, B. (2003). International Journal of Science Skill and will: The role of motivation and cognition in the learning of college chemistry, (December 2014), 37-41. https://doi.org/10.1080/0950069032000052207 